\title{
Recent studies on knowledge, attitude, and practice toward tuberculosis among university students
}

\author{
Lutfiah Yusuf ${ }^{1}$, Irma Melyani Puspitasari1 ${ }^{1,2^{*}}$, Rano Kurnia Sinuraya ${ }^{1,2}$ \\ ${ }^{1}$ Department of Pharmacology and Clinical Pharmacy, Faculty of Pharmacy, Universitas Padjadjaran, Jatinangor, Indonesia \\ ${ }^{2}$ Center of Excellence in Higher Education for Pharmaceutical Care Innovation, Universitas Padjadjaran, Jatinangor, Indonesia
}

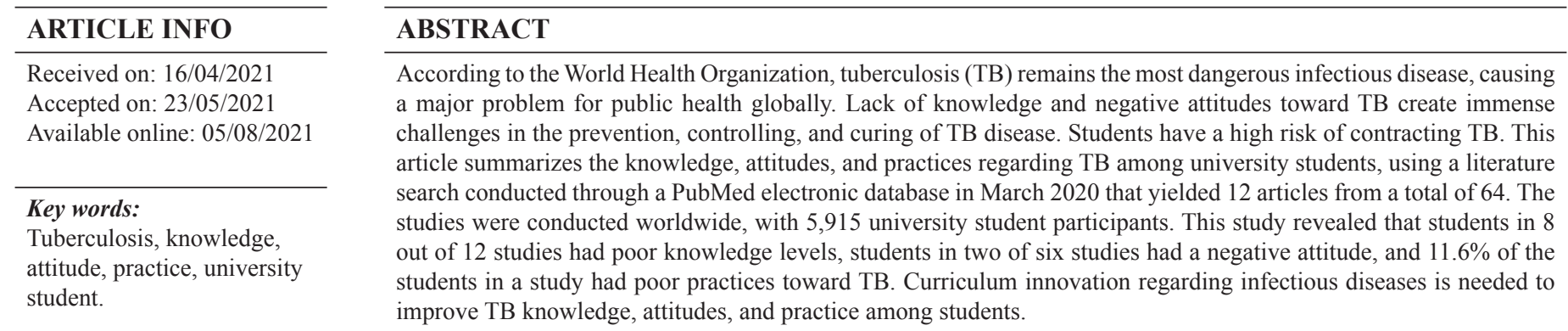

\section{INTRODUCTION}

Tuberculosis (TB) is an infectious disease caused by an acid-resistant bacterium called Mycobacterium tuberculosis and is one of the 10 main causes of death (Ministry of Health Republic of Indonesia, 2018). TB symptoms are divided into respiratory and systemic symptoms (Indonesian Society of Respirologist, 2019). Respiratory symptoms consist of coughing up phlegm for more than 3 weeks, bleeding cough, and shortness of breath, while systemic symptoms include fever, decreased body weight, and night sweats (Indonesian Society of Respirologist, 2019).

According to the World Health Organization (WHO), TB remains the most dangerous infectious disease and a major problem for global public health (World Health Organization, 2019). In 2018, the WHO estimated that 10 million people suffered from TB, with 1 case being equivalent to 132 cases per 100,000 people (World Health Organization, 2019).

\footnotetext{
"Corresponding Author

Irma Melyani Puspitasari, Department of Pharmacology and

Clinical Pharmacy, Faculty of Pharmacy, Universitas Padjadjaran,

SumedangJatinangor, Indonesia; Center of Excellence in Higher

Education for Pharmaceutical Care Innovation, Universitas Padjadjaran,

Jatinangor, Indonesia.E-mail: irma.melyani@unpad.ac.id
}

Research about the knowledge, attitude, and practice (KAP) has been frequently used in health studies. KAP research was also used as a research tool to obtain information known and believed among research participants (Haq et al., 2012). Therefore, KAP studies play an important role in determining community ambiguity (Haq et al., 2012).

A previous study has reported that a high prevalence of TB occurred among students in a university in Ethiopia (Wolde et al., 2017). A crowded environment and high-contact person-toperson environment in the universities and schools can be potential sources of disease transmission including TB (Dorji et al., 2020). It has been shown that lack of knowledge and negative attitudes toward TB are major problems in the prevention, controlling, and curing of TB disease (Luba et al., 2019). It is important to research KAP toward TB among students because students have a high risk of TB spread (Zhang et al., 2018). Therefore, this article summarizes the TB knowledge, attitudes, and practice research among university students.

\section{METHODS}

Literature searches were conducted in March 2020 through the PubMed electronic database. PubMed is a free search engine that comprises more than 32 million citations for biomedical literature from MEDLINE, life science journals, and online books. The keywords for literature search are "Knowledge," "Attitude," 
"Practice," "University student," and "TB." The following are the search details: ("knowledge" [MeSH Terms] OR "knowledge" [All Fields]) AND ("attitude" [MeSH Terms] OR "attitude" [All Fields]) AND ("Practice [Birm]" [Journal] OR "practice" [All Fields]) AND ("TB" [MeSH Terms] OR “TB” [All Fields]) AND ("universities" [MeSH Terms] OR "universities" [All Fields] OR "university" [All Fields]) AND ("students" [MeSH Terms] OR "students" [All Fields] OR "student" [All Fields]) NOT ("review" [Publication Type] OR "review literature as topic" [MeSH Terms] OR "review" [All Fields]). The initial search results yielded 64 articles. Articles prior to 2010 and non-English language were excluded. From 64 articles, 12 articles of knowledge, attitudes, and practices toward TB among university students were obtained. The literature search flowchart is shown in Figure 1.

\section{RESULTS AND DISCUSSION}

\section{Studies of knowledge, attitudes, and practices toward TB}

Table 1 shows 12 articles about knowledge, attitudes, and practices toward TB among students globally. All articles are cross-sectional studies; 11 used questionnaires as research instruments, while an additional article used the method of direct interviews with respondents. Respondents who participated in the studies are university healthcare and nonhealthcare students. Respondents totaled 5,915 students globally, ranging from 60 to 2,220 with random, convenience, and stratified random sampling techniques.

\section{TB knowledge among university students}

Table 2 shows the 12 articles presenting students' knowledge of TB. Nine articles were studies on university healthcare students and three articles on nonhealthcare university students.

Research on nonhealthcare students conducted in Bangladesh, Sweden, and Serbia revealed that they have a poor level of TB knowledge (Nkulu et al., 2010; Pesut, 2014; Rana et al., 2015). Students in Sweden have an average TB knowledge score of TB $2.7 \pm 1.3(\mathrm{SD})$ (maximum $=8$ ). Only 40 $(15 \%)$ out of 268 respondents answered correctly for half of the questions (Nkulu et al., 2010). In general, nonhealthcare students'

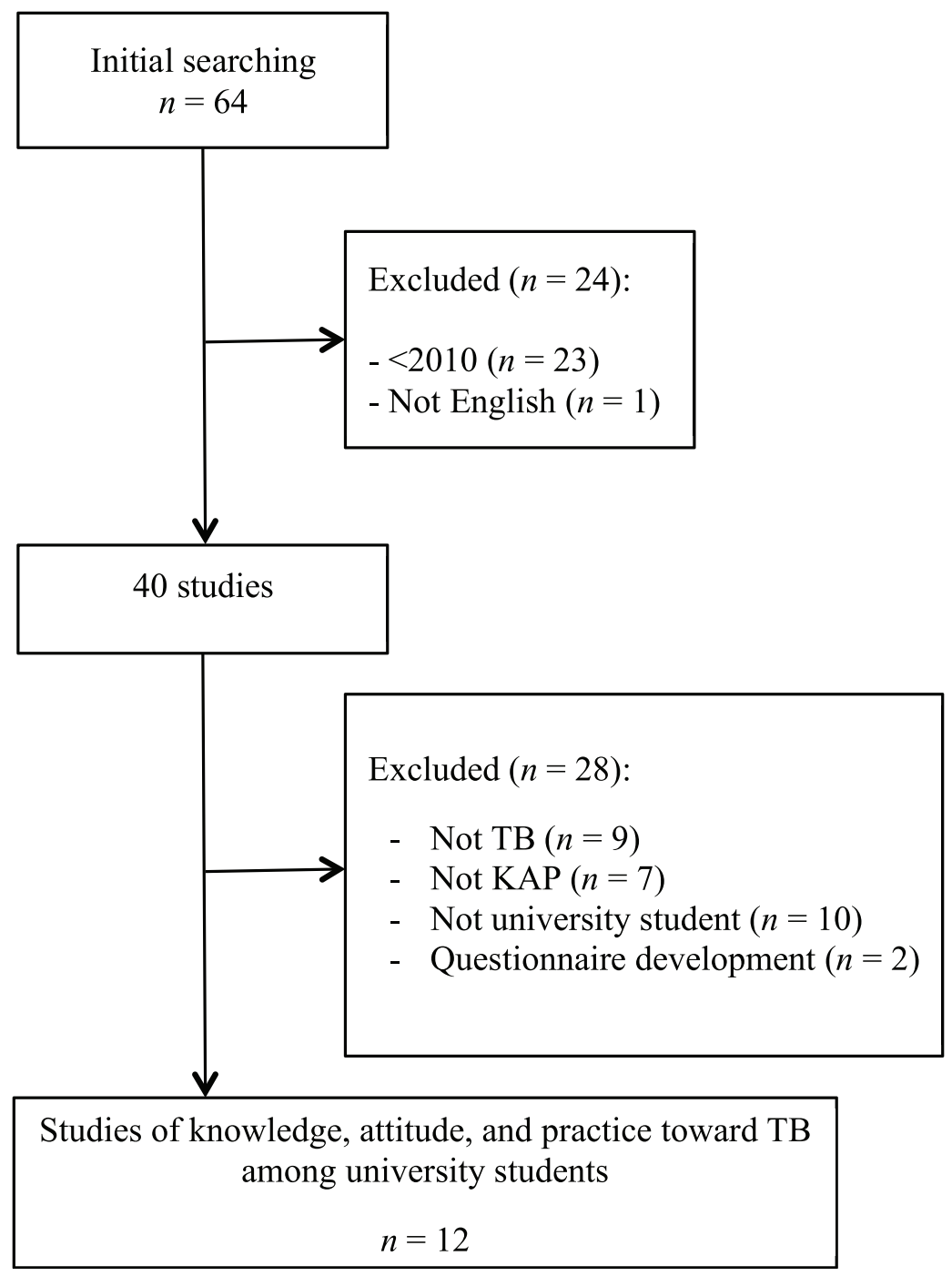

Figure 1. Flowchart of the literature search. 
Table 1. List of articles.

\begin{tabular}{|c|c|c|c|c|c|c|c|c|}
\hline Article no. & Author & Year & Country & Type of study & Participant type & $\begin{array}{c}\text { Number of } \\
\text { participants }\end{array}$ & Instrument & $\begin{array}{l}\text { Sampling } \\
\text { method }\end{array}$ \\
\hline 1 & Nkulu et al. (2010) & 2010 & Sweden & $\begin{array}{l}\text { Cross-sectional } \\
\text { study of KA }\end{array}$ & $\begin{array}{l}\text { Nonmedical } \\
\text { students }\end{array}$ & $n=280$ & Questionnaire & $\begin{array}{l}\text { Convenience } \\
\text { sampling }\end{array}$ \\
\hline 2 & Akin et al. (2011) & 2011 & Turkey & $\begin{array}{l}\text { Cross-sectional } \\
\text { study of KA }\end{array}$ & $\begin{array}{l}\text { Nursing and } \\
\text { midwifery students }\end{array}$ & $n=615$ & Questionnaire & $\begin{array}{l}\text { Convenience } \\
\text { sampling }\end{array}$ \\
\hline 3 & Pesut et al. (2014) & 2012 & Serbia & $\begin{array}{l}\text { Cross-sectional } \\
\text { study of KA }\end{array}$ & $\begin{array}{l}\text { Nonmedical } \\
\text { students }\end{array}$ & $n=69$ & Questionnaire & NA \\
\hline 4 & Traldi et al. (2012) & 2012 & Brazil & $\begin{array}{l}\text { Cross-sectional } \\
\text { study of K }\end{array}$ & Nursing students & $n=76$ & Questionnaire & NA \\
\hline 5 & Laurenti (2013) & 2013 & Italy & $\begin{array}{l}\text { Cross-sectional } \\
\text { study of KA }\end{array}$ & Medical students & $n=186$ & Questionnaire & NA \\
\hline 6 & $\begin{array}{l}\text { Montagna et al. } \\
\text { (2014) }\end{array}$ & 2014 & Italy & $\begin{array}{l}\text { Cross-sectional } \\
\text { study of K }\end{array}$ & $\begin{array}{l}\text { Medical and } \\
\text { nursing students }\end{array}$ & $n=2,220$ & Questionnaire & NA \\
\hline 7 & $\begin{array}{l}\text { Olakunle et al. } \\
\text { (2014) }\end{array}$ & 2014 & Nigeria & $\begin{array}{l}\text { Cross-sectional } \\
\text { study of K }\end{array}$ & Medical students & $n=241$ & Questionnaire & $\begin{array}{l}\text { Simple random } \\
\text { sampling }\end{array}$ \\
\hline 8 & $\begin{array}{l}\text { Behnaz et al. } \\
\text { (2014) }\end{array}$ & 2014 & Iran & $\begin{array}{l}\text { Cross-sectional } \\
\text { study of KAP }\end{array}$ & Medical students & $n=145$ & Questionnaire & NA \\
\hline 9 & Rana et al. (2015) & 2015 & Bangladesh & $\begin{array}{l}\text { Cross-sectional } \\
\text { study of K }\end{array}$ & $\begin{array}{l}\text { Nonmedical } \\
\text { students }\end{array}$ & $n=839$ & Interview & $\begin{array}{l}\text { Stratified random } \\
\text { sampling }\end{array}$ \\
\hline 10 & $\begin{array}{l}\text { Mckennon and and } \\
\text { J. Arnold (2016) }\end{array}$ & 2016 & America & $\begin{array}{l}\text { Cross-sectional } \\
\text { study of KA }\end{array}$ & $\begin{array}{l}\text { Pharmacist } \\
\text { students }\end{array}$ & $n=96$ & Questionnaire & NA \\
\hline 11 & Ou et al. (2018) & 2018 & China & $\begin{array}{l}\text { Cross-sectional } \\
\text { study of K }\end{array}$ & Medical students & $n=1,088$ & Questionnaire & $\begin{array}{l}\text { Randomized } \\
\text { sampling methods }\end{array}$ \\
\hline 12 & $\begin{array}{l}\text { de Fátima } \\
\text { Carvalho et al. } \\
\text { (2019) }\end{array}$ & 2019 & Brazil & $\begin{array}{l}\text { Cross-sectional } \\
\text { study of K }\end{array}$ & Nursing students & $n=60$ & Questionnaire & $\begin{array}{l}\text { Convenience } \\
\text { sampling }\end{array}$ \\
\hline & & & & \multicolumn{5}{|c|}{ Total $n=5,915$} \\
\hline
\end{tabular}

$\mathrm{K}=$ knowledge $\mathrm{A}=$ attitude; $\mathrm{P}=$ practice.

knowledge level in Bangladesh and Serbia is poor, and there are misconceptions about TB disease (Pesut, 2014; Rana et al., 2015).

Research in China, Rome, Brazil, and Nigeria showed that healthcare students have a poor level of knowledge of TB, answering more than $50 \%$ of the questions incorrectly (Ou et $a l ., 2018)$. Other questions that included basic inquiries relating to symptoms, diagnosis, and treatment were also answered incorrectly (de Fátima Carvalho et al., 2019; Laurenti, 2013; Olakunle et al., 2014; Ou et al., 2018; Traldi et al., 2012). The percentage of the total average correct answers regarding TB knowledge was $44.4 \%$ (SD 13.5\%) for healthcare students in China, while students in Rome have a percentage of $56.6 \%$ (SD 11.6\%) (Laurenti, 2013; Ou et al., 2018). Research in Iran showed that healthcare students have a medium to high level of knowledge (moderate to high) with a knowledge score of 16.13 \pm 2.06 (low $<10$, moderate 10-15, and high $>15)$ (Behnaz et al., 2014). Research in Italy compared the knowledge between medical and nursing students, revealing that medical students have better knowledge about TB compared to nursing students. The knowledge level of students in Italy was sufficient $(>60 \%$ of students answered questions correctly) (Montagna et al., 2014). Research in Turkey compared the knowledge of nursing and midwifery students with 615 participants (Akin et al., 2011). The result found a poor level of student knowledge, with a score of $7.22 \pm 1.92$ (Akin et al., 2011). The American study of pharmacist students used the Student Pharmacists as Tuberculosis Screeners
(SPATS) program created by the Washington State Pharmacy Association (Mckennon and Arnold, 2016). Students received training in TB epidemiology, pathophysiology, and treatment. Before and after conducting the training, students were asked to complete questionnaires about TB knowledge (Mckennon and Arnold, 2016). Before the SPATS program was conducted, the average score of students' knowledge about TB was $48.7 \%$ (SD $51.7 \%$ ); after the SPATS program was implemented, the average score was $86.5 \%$ (SD 55.5\%). This indicates that students' knowledge almost doubled following the SPATS program (Mckennon and Arnold, 2016).

\section{Attitude toward TB among university students}

Table 3 shows a list of articles discussing students' attitudes toward TB. Six articles discuss students' attitudes toward TB (two on nonhealthcare students and four on healthcare students). The nonhealthcare students in Sweden have an average score of $5.1 \pm 3.3(\mathrm{SD})$ (maximum $=12$ ), which shows that most students have a negative attitude toward TB disease and its patients (Nkulu et al., 2010). In Serbia, six out of eight nonmedical students did not visit TB patients for fear of contracting it, and 61 out of 69 students never wanted to be close to TB patients (Pesut, 2014). Negative attitudes toward TB disease and patients are caused by adverse stigma and cultural barriers. These negative attitudes affect not only TB sufferers but also their family members and closest relatives (Nkulu et al., 2010). 
Table 2. Knowledge among students.

\begin{tabular}{|c|c|c|c|c|c|c|}
\hline Article no. & Author & Country & Participant & Knowledge score & Knowledge result & Other results \\
\hline 1 & $\begin{array}{l}\text { Nkulu et al. } \\
\text { (2010) }\end{array}$ & Sweden & $\begin{array}{l}\text { Nonmedical } \\
\text { student }\end{array}$ & $\begin{array}{l}\text { Average } 2.7 \pm 1.3 \\
(\mathrm{SD})(\text { maximum }=8)\end{array}$ & $\begin{array}{l}\text { In general, nonhealthcare } \\
\text { students had poor } \\
\text { knowledge and } \\
\text { misconceptions about TB }\end{array}$ & $\begin{array}{l}\text { Most students knew well about the } \\
\text { symptoms, treatment, and risk factors } \\
\text { for TB but had poor knowledge about } \\
\text { the causes, transmission, diagnosis, } \\
\text { and prevention }\end{array}$ \\
\hline 3 & $\begin{array}{l}\text { Pesut et al. } \\
\text { (2014) }\end{array}$ & Serbia & $\begin{array}{l}\text { Nonmedical } \\
\text { student }\end{array}$ & NA & $\begin{array}{l}\text { Students' knowledge about } \\
\text { TB was at a poor level, } \\
\text { especially related to the } \\
\text { causes and transmission of } \\
\text { TB disease }\end{array}$ & $\begin{array}{l}\text { One in three students did not know the } \\
\text { symptoms of TB }\end{array}$ \\
\hline 9 & $\begin{array}{l}\text { Rana et al. } \\
(2015)\end{array}$ & Bangladesh & $\begin{array}{l}\text { Nonmedical } \\
\text { student }\end{array}$ & NA & $\begin{array}{l}\text { In general, the level of TB } \\
\text { knowledge in nonhealthcare } \\
\text { students was poor }\end{array}$ & $\begin{array}{l}\text { There is a significant relationship } \\
\text { between gender and knowledge about } \\
\text { the causes of TB }\end{array}$ \\
\hline 2 & $\begin{array}{l}\text { Akin et al. } \\
\text { (2011) }\end{array}$ & Turkey & $\begin{array}{l}\text { Nursing and } \\
\text { midwifery } \\
\text { Students }\end{array}$ & Average $7.22 \pm 1.92$ & $\begin{array}{l}\text { The level of student } \\
\text { knowledge was poor }\end{array}$ & $\begin{array}{l}\text { Students' knowledge about TB was } \\
\text { poor at TB treatment and vaccination }\end{array}$ \\
\hline 4 & $\begin{array}{l}\text { Traldi et al. } \\
\text { (2012) }\end{array}$ & Brazil & Nursing students & NA & $\begin{array}{l}\text { Nursing students showed } \\
\text { misconceptions about TB }\end{array}$ & $\begin{array}{l}\text { Nursing students were vulnerable } \\
\text { to TB contamination due to } \\
\text { misunderstanding of knowledge about } \\
\text { diagnosis, prevention, and biosafety }\end{array}$ \\
\hline 12 & $\begin{array}{l}\text { de Fátima } \\
\text { Carvalho et } \\
\text { al. (2019) }\end{array}$ & Brazil & Nursing students & NA & $\begin{array}{l}\text { Nursing students lack } \\
\text { knowledge about TB }\end{array}$ & $\begin{array}{l}\text { Basic questions related to symptoms, } \\
\text { diagnosis, and treatment were not } \\
\text { answered correctly }\end{array}$ \\
\hline 5 & $\begin{array}{l}\text { Laurenti } \\
(2013)\end{array}$ & Italy & Medical students & $\begin{array}{l}\text { Average } 56.6 \%(\mathrm{SD} \\
11.6 \%)\end{array}$ & $\begin{array}{l}\text { The level of student } \\
\text { knowledge was at the } \\
\text { moderate level }\end{array}$ & $\begin{array}{l}\text { More than half the questions about TB } \\
\text { treatment knowledge were answered } \\
\text { incorrectly, and there was a significant } \\
\text { relationship between knowledge and } \\
\text { clinical experience }\end{array}$ \\
\hline 6 & $\begin{array}{l}\text { Montagna } \\
\text { et al. }(2014)\end{array}$ & Italy & $\begin{array}{l}\text { Medical and } \\
\text { nursing students }\end{array}$ & $\begin{array}{l}\text { More than } 60 \% \text { of the } \\
\text { students answered } \\
\text { correct answer }\end{array}$ & $\begin{array}{l}\text { Knowledge of TB in } \\
\text { healthcare students was at a } \\
\text { sufficient level }\end{array}$ & $\begin{array}{l}\text { The level of knowledge of medical } \\
\text { students was better than that of nursing } \\
\text { students. Almost all students (up to } \\
95 \% \text { ) correctly answered questions } \\
\text { about TB knowledge in general } \\
\text { (etiology, clinical symptoms, and } \\
\text { antibiotic resistance) }\end{array}$ \\
\hline 7 & $\begin{array}{l}\text { Olakunle et } \\
\text { al. }(2014)\end{array}$ & Nigeria & Medical students & NA & $\begin{array}{l}\text { Medical students' } \\
\text { knowledge in the final } \\
\text { year was at a poor level for } \\
\text { various aspects of TB }\end{array}$ & $\begin{array}{l}\text { Only } 34.5 \% \text { were able to correctly } \\
\text { identify regimen treatment duration } \\
\text { according to standard guidelines }\end{array}$ \\
\hline 8 & $\begin{array}{l}\text { Behnaz et al. } \\
\text { (2014) }\end{array}$ & Iran & Medical students & $\begin{array}{l}\text { Average } 16.13 \pm 2.06 \\
(\text { low }<10, \text { moderate } \\
10-15, \text { and high }>15)\end{array}$ & $\begin{array}{l}\text { The majority of students } \\
\text { were at the medium to high } \\
\text { knowledge level }\end{array}$ & $\begin{array}{l}43 \% \text { of students did not know that } \\
\text { sputum examination was the most } \\
\text { important method for TB diagnosis. } \\
\text { Two out of three students also did } \\
\text { not know that they had to keep their } \\
\text { distance from TB patients }\end{array}$ \\
\hline 11 & $\begin{array}{l}\text { Ou et al. } \\
(2018)\end{array}$ & China & Medical students & $\begin{array}{l}\text { Average correct } \\
\text { answer } 44.4 \% \text { (SD } \\
13.5 \%)\end{array}$ & $\begin{array}{l}\text { Students generally have } \\
\text { poor knowledge about TB }\end{array}$ & $\begin{array}{l}\text { More than } 50 \% \text { of the total questions } \\
\text { about TB knowledge were answered } \\
\text { incorrectly. Medical students over } \\
23 \text { years old had more accurate } \\
\text { knowledge about TB diagnosis }\end{array}$ \\
\hline 10 & $\begin{array}{l}\text { Mckennon } \\
\text { and Arnold } \\
(2016)\end{array}$ & America & $\begin{array}{l}\text { Pharmacist } \\
\text { students }\end{array}$ & $\begin{array}{l}\text { Before and after } \\
\text { SPATS program: } \\
48.7 \% \text { (SD } 51.7 \%) \\
\text { and } 86.5 \% \text { (SD } \\
55.5 \% \text { ), respectively }\end{array}$ & $\begin{array}{l}\text { The SPATS program } \\
\text { significantly increases } \\
\text { student knowledge about TB }\end{array}$ & $\begin{array}{l}\text { Students' knowledge in therapy, } \\
\text { identification of TB patients, and } \\
\text { alternative methods of TB disease } \\
\text { screening increased after the SPAT } \\
\text { program }\end{array}$ \\
\hline
\end{tabular}

Iranian healthcare students have a score of $36.08 \pm 3.76$ (low 18-27, moderate 27-35, and high $>35$ ), indicating that the level of student attitudes was medium to high (moderate to high)
(Behnaz et al., 2014). A study in Turkey compared the attitudes of nursing students with midwifery students (Akin et al., 2011). The results showed that nursing and midwifery students generally have 
Table 3. Attitude among students.

\begin{tabular}{|c|c|c|c|c|c|c|}
\hline Article no. & Author & Country & Participant & Attitude score & Attitude result & Other results \\
\hline 1 & $\begin{array}{l}\text { Nkulu et al. } \\
\text { (2010) }\end{array}$ & Sweden & Nonmedical students & $\begin{array}{l}5.1 \pm 3.3(\mathrm{SD}) \\
(\operatorname{maximum}=12)\end{array}$ & $\begin{array}{l}\text { Nonhealthcare students had a } \\
\text { negative attitude toward TB } \\
\text { disease and TB patients }\end{array}$ & $\begin{array}{l}\text { Most respondents would hide } \\
\text { if they have TB and were } \\
\text { worried about the response of } \\
\text { people around them }\end{array}$ \\
\hline 3 & $\begin{array}{l}\text { Pesut et al. } \\
(2014)\end{array}$ & Serbia & Nonmedical students & NA & $\begin{array}{l}\text { Students have a good attitude } \\
\text { toward disease and TB patients }\end{array}$ & $\begin{array}{l}78 \% \text { of the participants will } \\
\text { visit TB patients without fear } \\
\text { of contracting the disease }\end{array}$ \\
\hline 2 & $\begin{array}{l}\text { Akin et al. } \\
\text { (2011) }\end{array}$ & Turkey & $\begin{array}{l}\text { Nursing and } \\
\text { midwifery students }\end{array}$ & NA & $\begin{array}{l}\text { Nursing and midwifery } \\
\text { students generally have a } \\
\text { negative attitude }\end{array}$ & $\begin{array}{l}\text { The attitude of nursing } \\
\text { students is better than } \\
\text { midwifery students }\end{array}$ \\
\hline 5 & Laurenti (2013) & Italy & Medical students & NA & $\begin{array}{l}\text { Half of the students had a } \\
\text { positive attitude toward TB } \\
\text { patients }\end{array}$ & $\begin{array}{l}57.6 \% \text { of the students felt that } \\
\text { they had a risk of contracting } \\
\text { TB }\end{array}$ \\
\hline 8 & $\begin{array}{l}\text { Behnaz et al. } \\
(2014)\end{array}$ & Iran & Medical students & $\begin{array}{l}36.08 \pm 3.76(\text { low } \\
18-27, \text { moderate } \\
27-35, \text { and high }>35)\end{array}$ & $\begin{array}{l}\text { Student attitudes were at the } \\
\text { medium to high level }\end{array}$ & $\begin{array}{l}60 \% \text { of the students wear } \\
\text { masks when in contact with } \\
\text { TB patients }\end{array}$ \\
\hline 10 & $\begin{array}{l}\text { Mckennon and } \\
\text { Arnold (2016) }\end{array}$ & America & Pharmacist students & NA & $\begin{array}{l}\text { There was a significant change } \\
\text { in attitude after the SPATS } \\
\text { program }\end{array}$ & $\begin{array}{l}\text { Students are willing to do TST } \\
\text { and realize that pharmacists } \\
\text { have an important role in } \\
\text { conducting TSTs }\end{array}$ \\
\hline
\end{tabular}

Table 4. Practice among students.

\begin{tabular}{|c|c|c|c|c|c|c|}
\hline Study no. & Author & Country & Participant & Practice score & Practice result & Other results \\
\hline 8 & $\begin{array}{l}\text { Behnaz et al. } \\
(2014)\end{array}$ & Iran & Medical students & $\begin{array}{l}\text { Average } 22.77 \pm 4.95 \text { (low } \\
<20 \text {, moderate } 20-25 \text {, and } \\
\text { high }>25 \text { ) }\end{array}$ & $\begin{array}{l}\text { Student practice was } \\
\text { at the moderate level }\end{array}$ & $\begin{array}{l}\text { Practice scores for female students were } \\
\text { better than those for male students. One } \\
\text { in four students had the habit of washing } \\
\text { hands before and after contact with patients }\end{array}$ \\
\hline
\end{tabular}

a negative attitude, but nursing students' attitudes are better (Akin et al., 2011). The study of pharmacist students in the USA using the SPATS program resulted in significant changes in attitudes toward TB and the willingness to perform a tuberculin skin test (TST) (Mckennon et al., 2016). Students also realized that pharmacists are beneficial regarding TSTs (Mckennon et al., 2016).

\section{Practice toward TB among university students}

Table 4 presents an article discussing students' practice toward TB. The student practice study was only found in final year students conducted in Yazd, Central Iran (Behnaz et al., 2014). The mean practice score was $22.27 \pm 4.95$ (low $<20$, moderate 20-25, and high $>25$ ), and $11.9 \%$ of students had poor practice levels. The practice scores for female students were better than those for male students. In addition, one out of four students had the habit of washing hands before and after being in contact with patients. Students had an effective practice of wearing masks (70.2\%), with $60 \%$ of the students wearing a mask when in contact with TB patients. Half of the students keep a distance from TB patients. The practice relating to medication is not yet evaluated, because the students are still guided by a supervisor. Nevertheless, 95.1\% of the students have known that the standard TB medication is taken for 6 months (Behnaz et al., 2014).

\section{Effort to increase KAP in students}

This study revealed poor levels of knowledge for students in 8 of 12 studies; students had a negative attitude in two out of six studies, with one study revealing poor practices in $11.6 \%$ of students. KAP improvement must be carried out to help control and prevent TB (Hassan et al., 2017). Poor TB knowledge is one of the main problems in preventing, controlling, and curing TB disease (Luba et al., 2019). In students, poor knowledge was caused by a lack of literacy skills and misconceptions, indicating that curriculum innovation regarding infectious diseases is needed to increase students' TB knowledge (Laurenti, 2013). Training for pharmacy students in the USA, such as the SPATS program that comprises TB epidemiology, pathophysiology, and treatment, could be conducted to increase knowledge and attitudes among students (Gudeva et al., 2012; Mckennon and Arnold, 2016). The training program resulted in significant changes in students' knowledge and attitudes toward TB.

\section{Limitation}

There are limitations to this review. The literature search was only conducted in one electronic database; nevertheless, this article could provide an overview of knowledge, attitudes, and practice toward TB among students worldwide.

\section{CONCLUSION}

This article summarizes the knowledge, attitudes, and practices toward TB among university healthcare and nonhealthcare students. Students in 8 out of 12 studies had poor knowledge levels, students in two out of six studies had a negative attitude, and $11.6 \%$ of students in a study still have poor practices. 
Curriculum innovation regarding infectious diseases is needed to improve students' TB knowledge, attitudes, and practices.

\section{CONFLICT OF INTEREST}

The authors report no conflicts of interest.

\section{FUNDING}

This work was supported by the Ministry of Research and Technology and Higher Education, Indonesia (grant number 1123j/UN6.O/LT/2019).

\section{AUTHOR CONTRIBUTIONS}

All authors made substantial contributions to conception and design, acquisition of data, or analysis and interpretation of data; took part in drafting the article or revising it critically for important intellectual content; agreed to submit to the current journal; gave final approval of the version to be published; and agree to be accountable for all aspects of the work. All the authors are eligible to be an author as per the international committee of medical journal editors (ICMJE) requirements/guidelines.

\section{ETHICAL APPROVALS}

Not applicable.

\section{PUBLISHER'S NOTE}

This journal remains neutral with regard to jurisdictional claims in published institutional affiliation.

\section{REFERENCES}

Akin S, Gorak G, Unsar S, Mollaoglu M, Ozdilli K, Durna Z. Nurse education today knowledge of and attitudes toward tuberculosis of Turkish nursing and midwifery students. Nurse Educ Today, 2011; 31(8):774-9.

Behnaz F, Mohammadzade G, Mousavi-e-roknabadi RS, Mohammadzadeh M. Assessment of knowledge, attitudes and practices regarding tuberculosis among final year students in Yazd, central Iran. J Epidemiol Glob Health, 2014; 4:81-85.

de Fátima Carvalho C, Ponce MAZ, da Silva-Sobrinho RA, Mendez RDR, Santos MAD, Santos EMD, Wysocki AD. Tuberculosis: knowledge among nursing undergraduate students. Rev Bras Enferm, 2019; 72(5):1279-87.

Dorji T, Tshering T, Wangdi K. Assessment of knowledge, attitude and practice on tuberculosis among teacher trainees of Samtse College of Education, Bhutan. PLoS One, 2020; 15(11):e0241923.

Gudeva Nikovska D, Talevski S. How much knowledge is healthy? Result of KAP survey of TB patients in Republic of Macedonia. Eur Respir J, 2012; 40(56):2671.

Haq N, Hassali MA, Shafie AA, Saleem F, Farooqui M, Aljadhey $\mathrm{H}$. A cross sectional assessment of knowledge, attitude and practice towards Hepatitis B among healthy population of Quetta, Pakistan. BMC Public Health, 2012; 12(1):1.

Hassan AO, Olukolade R, Ogbuji QC, Afolabi S, Okwuonye LC, Kusimo OC, Osho JA, Osinowo KA, Ladipo OA. Knowledge about tuberculosis: a precursor to effective TB control - findings from a followup national KAP study on tuberculosis among Nigerians. Tuberc Res Treat, 2017; 2017:6309092.

Indonesian Society of Respirologist. Guidelines for diagnosis and management tuberculosis in Indonesia. Indonesian Society of Respirologist, Jakarta, Indonesia, 2006.
Laurenti P. Knowledge, experiences, and attitudes of medical students in Rome about tuberculosis. Med Sci Monit, 2013; 19:865-74.

Luba TR, Tang S, Liu Q, Gebremedhin SA, Kisasi MD. Knowledge, attitude and associated factors towards tuberculosis in Lesotho: a population based study. BMC Infect Dis 2019; 19(96):1-10.

Mckennon SA, Arnold J. Student pharmacists as tuberculosis screeners. Am J Pharm Educ, 2016; 80(2):1-6.

Ministry of Health Republic of Indonesia. INFODATIN (Data and Information Center Ministry of Health) find TB cases treat until healed. Ministry of Health Republic of Indonesia, Jakarta, Indonesia, 2018.

Montagna MT, Napoli C, Tafuri S, Agodi A, Auxilia F, Casini B, Coscia MF, D'Errico MM, Ferrante M, Fortunato A, Germinario C, Martinelli D, Masanotti GM, Massenti MF, Messina G, Montuori P, Mura I, Orsi GB, Quaranta A, Sotgiu G, Stefanati A, Tardivo S, Torregrossa MV, Tortorano AM, Veronesi L, Zarrilli R, Pasquarella C. Knowledge about tuberculosis among undergraduate health care students in 15 Italian universities : a cross-sectional study. BMC Public Health, 2014; 14(970): $1-6$.

Nkulu FKK, Hurtig A, Ahlm C, Krantz I. Screening migrants for tuberculosis - a missed opportunity for improving knowledge and attitudes in high-risk groups: a cross-sectional study of Swedish-language students in Umeå, Sweden. BMC Public Health, 2010; 10(349):1-12.

Olakunle OS, Oladimeji O, Olalekan AW, Olugbenga-Bello A, Akinleye C, Oluwatoyin OA. Knowledge of tuberculosis management using directly observed treatment short course therapy among final year medical students in South Western Nigeria. Pan Afr Med J, 2014; 18:32.

Ou Y, Luo Z, Mou J, Ming H, Wang X, Yan S, Tan A. Knowledge and determinants regarding tuberculosis among medical students in Hunan, China: a cross-sectional study. BMC Public Health, 2018; 18(730):1-7.

Pesut DP. Knowledge and attitudes towards tuberculosis in non medical students university of belgrade. Pneumologia, 2014; 61(2):87-91.

Rana M, Sayem A, Karim R, Islam N, Islam R, Zaman TK. Assessment of knowledge regarding tuberculosis among non-medical university students in Bangladesh: a cross-sectional study. BMC Public Health, 2015; 15(716):1-7.

Traldi MC, Nery J, Talarico S. Knowledge as a factor in vulnerability students and professionals. Rev Esc Enferm USP, 2012; 46(3):696-703.

Wolde D, Tadesse M, Abdella K, Abebe G, Ali S. Tuberculosis among Jimma University undergraduate students: first insight about the Burden of tuberculosis in Ethiopia universities-cross-sectional study. Int $\mathrm{J}$ Bacteriol, 2017; 2017:9840670.

World Health Organization. Global tuberculosis report 2019. World Health Organization, Geneva, Switzerland, 2019.

Zhang S, Li Y, Li Y, Zhang T, Liu W, Jiang H. Development and psychometric testing of the knowledge, attitudes and practices (KAP) questionnaire among student Tuberculosis (TB) Patients (STBP-KAPQ) in China. BMC Infect Dis 2018; 18(213):1-10.

How to cite this article:

Yusuf L, Puspitasari IM, Sinuraya RK. Recent studies on knowledge, attitude, and practice toward tuberculosis among university students. J Appl Pharm Sci, 2021; 11(08):178-183. 